\title{
Antioxidant activity of methanolic extract from yellow paprika (Capsicum annuum, L.) by DPPH radical scavenging method
}

\section{Aktivitas antioksidan ekstrak metanol paprika kuning (Capsicum annuum, L.) dengan metode penangkapan radikal DPPH}

\author{
Warsi ${ }^{*}$, Any Guntarti \\ Fakultas Farmasi Universitas Ahmad Dahlan \\ Jl. Prof. Dr. Soepomo, S.H., Janturan, Yogyakarta
}

\begin{abstract}
ABSTRAK
Paprika kuning (Capsicum annuum L.) merupakan salah satu buah yang mengandung senyawa karotenoid sebagai antioksidan. Penelitian ini bertujuan untuk mengetahui daya antioksidan ekstrak metanol buah paprika kuning dengan metode penangkapan radikal 2,2-difenil-1-pikrilhidrazil (DPPH). Buah paprika kuning segar ditetapkan susut pengeringan secara gravimetri. Ekstrak paprika kuning diperoleh dengan cara maserasi menggunakan pelarut metanol. Ekstrak kemudian dianalisis kandungan $\beta$-karotennya secara kualitatif dengan kromatografi lapis tipis dan spektrofotometer UVVis. Aktivitas antioksidan dari ekstrak metanol paprika kuning ditetapkan berdasarkan pengukuran sisa DPPH dengan spektrofotometer UV-Vis pada panjang gelombang 515,6 nm. Data hasil pengukuran ini kemudian digunakan untuk menghitung $\%$ inhibisi. Selanjutnya, ditentukan nilai $\mathrm{IC}_{50}$ untuk mengetahui potensi antioksidannya. Hasil penetapan susut pengeringan buah paprika kuning diperoleh $6,33 \pm 0,02 \%$. Berdasarkan hasil analisis dengan kromatografi lapis tipis dan spektrofotometer UV-Vis, buah paprika kuning mengandung $\beta$-karoten. Hasil analisis aktivitas antioksidan buah paprika kuning diperoleh nilai $\mathrm{IC}_{50}$ sebesar $0,3028 \pm 0,0093 \mathrm{mg} / \mathrm{mL}$. Hasil penelitian menunjukkan bahwa potensi antioksidan paprika kuning kurang poten apabila dibandingkan dengan $\beta$-karoten $\left(\mathrm{IC}_{50} 0,0852 \pm 0,0009 \mathrm{mg} / \mathrm{mL}\right)$.
\end{abstract}

Kata kunci : antioksidan, paprika kuning, Capsicum annuum, DPPH

\section{ABSTRACT}

Yellow paprika (Capsicum annuиm L.) is one of fruit that contains of carotenoid compounds as an antioxidant. This reasearch was aimed to know an antioxidant capacity of methanolic extract from yellow paprika with 2,2-diphenyl-1-picrylhydrazyl (DPPH) radical scavenging method. The fresh yellow paprika was determined of its loss of drying by gravimetric. The yellow paprika extract was obtained by maceration using methanol as solvent. The content of $\beta$-carotene from this extract was analyzed qualitively by thin layer chromatography and UV-Vis spectrophotometer. The antioxidant activity of methanolic extract from yellow paprika was determined base on measurement of residual DPPH by UV-Vis spectrophothometric at wavelength of $515.6 \mathrm{~nm}$.

\footnotetext{
Penulis korespondesi:

Warsi

Fakultas Farmasi Universitas Ahmad Dahlan

J1. Prof. Dr. Soepomo, S.H., Janturan, Yogyakarta

Email: warsisuryatmoko@gmail.com
} 
The data was used to calculate $\%$ inhibition. Furthermore, $\mathrm{IC}_{50}$ value was determined to know potency of its antioxidant. The result of loss of drying yellow paprika fruit was obtained $6.33 \pm 0.02 \%$. The analysis with thin layer chromatography and UV-Vis spectrophotometer showed that this fruit was contain of $\beta$-carotene. The result of antioxidant activity analysis from yellow paprika fruit was obtained $\mathrm{IC}_{50}$ value of $0.3028 \pm 0.0093 \mathrm{mg} / \mathrm{mL}$. The result of the research showed that the antioxidant potency of yellow paprika was less than $\beta$-carotene $\left(\mathrm{IC}_{50} 0.0852 \pm 0.0009 \mathrm{mg} / \mathrm{mL}\right.$ ).

Key words : antioxidant, yellow paprika, Capsicum annuum, DPPH

\section{PENDAHULUAN}

Kerusakan sel disebabkan oleh adanya radikal bebas yang dapat mengakibatkan proses penuaan dini dan berperan dalam timbulnya berbagai penyakit. Radikal bebas dapat timbul secara alami di dalam tubuh karena adanya proses metabolisme lemak, protein dan karbohidrat untuk menghasilkan energi. Radikal bebas dapat berupa reactive oxygen species (ROS), terdiri dari : radikal hidroksi, radikal anion superoksida, hidrogen peroksida, oksigen, radikal nitrit oksida, radikal hipoklorida dan lipid peroksida. Radikal bebas tersebut dapat menyerang sel tubuh dan menyebabkan kehilangan struktur dan fungsinya. Radikal bebas nampaknya berkontribusi terhadap patogenesis berbagai penyakit kronik, yang menyerang lipid, asam nukleat dan protein. Penyakit-penyakit yang ditimbulkan oleh adanya serangan radikal bebas diantaranya ialah aterosklerosis, kanker, disfungsi paru-paru, katarak, artritis, inflamasi, diabetes, iskemia, ginjal, pankreatitis, parkinson, lesi kulit dan penuaan dini (Gülçin, 2007; Percival, 1998).

Tubuh memerlukan antioksidan untuk menstabilkan radikal bebas sebelum menyerang sel hidup. Antioksidan dapat berupa endogen dan eksogen yang fungsinya sinergis untuk menetralkan radikal bebas. Antioksidan endogen berupa enzim-enzim, diantaranya ialah superoksida dismutase, glutation peroksidase dan glutation reduktase. Enzim-enzim tersebut mengkatalisis reaksi peredaman rdikal bebas. Antioksidan endogen juga dapat berupa logam yang terikat protein, diantaranya yaitu: ferritin, laktoferrin, albumin serta seruloplasmin yang mengikat ion besi dan ion tembaga. Antioksidan tersebut mampu mengkatalisis reaksi oksidasi (Percival, 1998).

Namun dengan antioksidan endogen saja tidak cukup untuk menetralkan radikal bebas yang dihasilkan setiap harinya oleh tubuh. Oleh karena itu, diperlukan senyawa antioksidan eksogen. Komponen yang aktif sebagai antioksidan dapat berasal dari tanaman, diantaranya ialah buah. Buah merupakan makanan yang ekselen, dengan karakteristik kandungan kalori rendah dan antioksidannya tinggi. Buah dengan kandungan antioksidannya mampu mencegah berbagai patologis, diantaranya ialah kanker, kardiovaskuler, diabetes dan penyakit degenatif yang berhubungan dengan proses penuaan (Tundis et al., 2013).

Paprika kuning (Capsicum annuum L.) merupakan salah satu buah yang mengandung banyak senyawa yang aktif sebagai antioksidan. Kandungan buah paprika kuning yang masak diantaranya ialah: senyawa fenol 666,0 mg/100 g bahan; flavonoid 39,0 mg/100 g bahan dan karotenoid dihitung terhadap $\beta$-karoten (Gambar 1A) sebesar 130,6 mg/100 g bahan. Paprika kuning juga mengandung kapsaisin (Gambar 1B) sebanyak 415,8 $\mu \mathrm{g} / 100 \mathrm{~g}$ bahan dan dihidrokapsaisin (Gambar 1C) sebesar $545,8 \mu \mathrm{g} / 100 \mathrm{~g}$ bahan (Tundis et al., 2013). Selain itu, paprika kuning juga mengandung likopen, fenol dan vitamin C sebesar 131,21 mg/100 g bahan kering (Cháves-Mendosa et al., 2015) serta mineral (Jeong et al., 2006).

Adanya kandungan senyawa dalam paprika kuning yang berpotensi sebagai antioksidan, sehingga perlu dibuktikan secara ilmiah. Dalam pengujian antioksidan in vitro, 2,2-difenil-1pikrilhidrazil (DPPH) digunakan secara luas sebagai model radikal bebas, karena senyawa tersebut stabil. DPPH merupakan senyawa yang mengandung gugus dengan elektron tidak berpasangan (Sharma and Bhat, 2009). 
A<smiles>CC1=C(/C=C/C(C)=C/C=C/C(C)=C/C=C/C=C(C)/C=C/C=C(C)/C=C/C2=C(C)CCCC2(C)C)C(C)(C)CCC1</smiles>

B<smiles>COc1cc(CNC(=O)CCCC/C=C/C(C)C)ccc1O</smiles>

C<smiles>COc1cc(CNC(=O)CCCCCCC(C)C)ccc1O</smiles>

\section{Gambar 1. Struktur $\beta$-karoten [A]; kapsaisin [B]; dihidrokapsaisin [C]} (Kim et al., 2016; Reyes-Escogido et al., 2011)

Aktivitas antioksidan ekstrak etanol paprika kuning sebelumnya telah diteliti oleh Tundis et al. (2013), dengan metode penangkapan radikal DPPH dan $\beta$-carotene bleaching test. Peneliti lain juga telah menguji aktivitas antioksidan ekstrak etanol paprika kuning buah segar yang diambil dalam tiga periode bulan yang berbeda yaitu Juli, Agustus dan September dengan metode penangkapan radikal DPPH. Aktivitas antioksidan yang paling tinggi adalah buah yang disampling pada bulan September (Cháves-Mendosa et al., 2015). Pengujian aktivitas antioksidan kali ini dilakukan terhadap ekstrak metanol buah paprika kuning segar dengan metode penangkapan radikal DPPH. Metanol, dalam penelitian ini digunakan sebagai pelarut karena sifatnya yang semi polar. Penggunaan pelarut tersebut diharapkan semua senyawa dapat tersari secara sempurna, baik yang bersifat polar maupun non polar, sehingga aktivitas antioksidannya juga lebih baik.

\section{METODE PENELITIAN}

\section{Alat dan Bahan}

Peralatan yang digunakan dalam penelitian ini yaitu: spektrofotometer UV-Vis (Pharmaspec 1700, SHIMADZU), rotary evaporator (Buchi), timbangan analitik, blender, sonikator ultrasonic T 570 dan lampu UV. Sampel berupa buah paprika kuning masak yang masih segar, diperoleh dari supermarket Indogrosir Jalan Magelang, Sleman, Daerah Istimewa Yogyakarta. Bahan-bahan lain diantaranya ialah: 2,2-difenil-1-pikrilhidrazil (DPPH) (E Merck, Darmstadt, Jerman), $\beta$-karoten (Sigma-Aldrich, Milano, Italy), metanol (E Merck), aquadest, natrium sulfat anhidrat (E Merck), lempeng silika $\mathrm{GF}_{254}$ (E Merck). Semua bahan yang digunakan dalam penelitian ini berderajat pro analisis.

\section{Jalannya Penelitian \\ Penetapan susut pengeringan buah paprika kuning}

Buah paprika kuning segar yang telah diiris kecil-kecil ditimbang 10 gram, dimasukkan dalam cawan petri yang sebelumnya telah dipanaskan pada suhu $105^{\circ} \mathrm{C}$ selama 30 menit dan ditara. Dikeringkan di oven pada suhu $105^{\circ} \mathrm{C}$ selama 24 jam. Cawan dimasukkan ke dalam eksikator, dibiarkan dingin kemudian ditimbang. Pengeringan dilanjutkan sampai bobot tetap (Anonim, 1979).

\section{Ekstraksi buah paprika kuning}

Buah paprika kuning segar diekstraksi dengan maserasi menggunakan pelarut metanol dengan perbandingan 1:1. Buah yang sudah dicuci bersih diblender. Buah halus sebanyak 200,0 gram ditambahkan metanol $200 \mathrm{~mL}$. Simplisia diaduk 2 jam dengan pengaduk elektrik, kemudian didiamkan selama 24 jam dalam wadah tertutup rapat. Setelah pendiaman disaring dengan corong Büchner, 
diperoleh filtrat I. Ampas diremaserasi dengan cara yang sama hingga diperoleh filtrat II, III dan IV. Filtrat dikumpulkan menjadi satu dan dikeringkan dengan ditambahkan $8 \mathrm{~g}$ natrium sulfat anhidrat. Selanjutnya, filtrat diuapkan dengan vacuum rotary evaporator pada suhu $65^{\circ} \mathrm{C}$ hingga diperoleh ekstrak kental. Ekstrak kental yang diperoleh ditimbang.

\section{Analisis kandungan $\beta$-karoten dalam ekstrak paprika kuning}

Analisis kandungan $\beta$-karoten dalam ekstrak paprika kuning dilakukan secara kualitatif dengan kromatografi lapis tipis (KLT). Ekstrak buah paprika kuning dibuat konsentrasi $10 \mathrm{mg} / \mathrm{mL}$ dalam metanol. $\beta$-karoten digunakan sebagai standar dan dibuat konsentrasinya $5 \mathrm{mg} / \mathrm{mL}$ dalam metanol. Fase diam (FD) yang digunakan ialah lempeng silika $\mathrm{GF}_{254}$ ukuran 5 x $10 \mathrm{~cm}$. Fase geraknya (FG) terdiri dari campuran n-heksan-aseton dengan 2 jenis perbandingan, masing-masing $1: 2$ dan $3: 2$ (Purwitasari, 2017). Ekstrak ditotolkan pada plate kromatografi $10 \mu \mathrm{L}$, sedangkan $\beta$-karoten sebanyak $5 \mu \mathrm{L}$. Plate kemudian dikembangkan dalam chamber yang telah jenuh dengan eluennya. Identifikasi terhadap senyawa dilakukan dengan sinar tampak. Spot ditandai dan masing-masing dihitung Rfnya.

Analisis kandungan $\beta$-karoten dalam ekstrak paprika kuning juga dilakukan berdasarkan spektrumnya. Larutan ekstrak paprika kuning dengan konsentrasi $0,32 \mathrm{mg} / \mathrm{mL}$ dibuat dalam metanol. Larutan diukur dengan spektrofotometer UV-Vis pada panjang gelombang 200-550 nm.

\section{Analisis aktivitas antioksidan Penyiapan larutan DPPH 0,4 mM}

Dibuat larutan stok DPPH dengan konsentrasi $1 \mathrm{mM}$. Larutan tersebut dibuat dengan ditimbang DPPH sebanyak 9,8 mg, dilarutkankan dalam metanol hingga volumenya 25,0 mL. Larutan stok $1 \mathrm{mM}$ kemudian diencerkan menjadi $0,4 \mathrm{mM}$ dengan dipipet sebanyak $10,0 \mathrm{~mL}$ dan ditambahkan metanol hingga volumenya $25,0 \mathrm{~mL}$ (Warsi dan Guntarti, 2016).

\section{Penentuan serapan sampel}

Ekstrak paprika kuning dibuat larutan dalam metanol. Seri konsentrasi yang diukur ialah : 0,08; 0,$16 ; 0,24 ; 0,32 ; 0,40 ; 0,48$; dan 0,56 mg/ mL. Masing-masing seri konsentrasi dipipet 2,4 ml, kemudian ditambahkan 0,6 ml larutan DPPH 0,4 mM. Campuran larutan divorteks, kemudian didiamkan ditempat gelap selama 90 menit. Sampel diukur serapannya dengan spektrofotometer UVVis pada $\lambda$ maksimum 515,6 nm terhadap blanko. Blanko yang digunakan ialah masing-masing seri larutan sampel sebanyak 2,4 $\mathrm{ml}$ dan ditambahkan $0,6 \mathrm{ml}$ metanol.

\section{Penentuan serapan pembanding}

Pembanding yang digunakan dalam penelitian ini ialah $\beta-$ karoten. Seri konsentrasi larutan $\beta$ karoten yang digunakan yaitu 0,$02 ; 0,04 ; 0,06 ; 0,08 ; 0,10 ; 0,12$ dan $0,14 \mathrm{mg} / \mathrm{mL}$. Masing-masing seri konsentrasi dipipet 2,4 $\mathrm{mL}$ dan ditambahkan 0,6 ml larutan DPPH 0,4 mM. Campuran divorteks, kemudian didiamkan ditempat gelap selama 90 menit. Serapan larutan $\beta$-karoten diukur dengan spektrofotometer UV-Vis pada $\lambda$ maksimum $515,6 \mathrm{~nm}$ terhadap blanko. Blanko yang digunakan yaitu masing-masing seri larutan $\beta$-karoten diambil 2,4 ml kemudian ditambahkan 0,6 ml metanol.

\section{Penentuan serapan kontrol negatif}

Sebanyak 0,6 mL larutan DPPH 0,4 mM ditambahkan 2,4 $\mathrm{mL}$ metanol. Campuran didiamkan selama 90 menit. Serapannya diukur dengan spektrofotometer UV-Vis pada $\lambda$ maksimum $515,6 \mathrm{~nm}$ terhadap blanko. Metanol digunakan sebagai blanko.

\section{Analisis Data}

Aktivitas antioksidan sampel dinyatakan dengan besaran $\mathrm{IC}_{50}$ (inhibition Concentration $50 \%$ ). Untuk menentukan parameter tersebut terlebih dahulu dihitung \% inhibisi. Hasil perhitungan \% inhibisi kemudian digunakan untuk membuat persamaan regresi linier hubungan dengan konsentrasi sampel. Angka 50 selanjutnya dimasukkan ke sumbu y pada persamaan regresi linier yang telah diperoleh sehingga diperoleh nilai $\mathrm{IC}_{50}$. 


$$
\% \text { Inhibisi }=\frac{\text { Absorbansi Kontrol }- \text { Absorbansi Sampel }}{\text { Absorbansi Kontrol }} \times 100 \%
$$

Hasil perhitungan nilai $\mathrm{IC}_{50}$ kemudian dibandingkan dengan $\beta$-karoten dan dianalisis secara statistika menggunakan SPSS 12 pada taraf kepercayaan $95 \%$. Analisis yang digunakan yaitu uji Kolmogorov-Smirnov serta uji Levene, yang bertujuan untuk mengetahui normalitas dan homogenitasnya. Apabila data terdistribusi normal dan homogen dilanjutkan dengan uji parametrik. Namun apabila data tidak terdistribusi normal dan homogen atau salah satu, dilanjutkan analisis non parametrik yaitu uji Mann Whitney, untuk mengetahui signifikansi antara dua sampel.

\section{HASIL DAN PEMBAHASAN}

\section{Hasil penetapan susut pengeringan paprika kuning}

Paprika kuning ditetapkan susut pengeringan dengan metode gravimetri berdasarkan kehilangan dari bobot semula yaitu simplisia basah. Paprika kuning selain mengandung air juga terdapat asamasam lemak yang dapat mempengaruhi hasil. Hasil penetapan susut pengeringan paprika kuning tersajikan pada Tabel I. Berdasarkan hasil tersebut, susut pengeringan paprika kuning kurang dari 10 $\%$. Hal ini memenuhi persyaratan \% susut pengeringan yang tertera pada Farmakope Herbal Indonesia secara umum (Anonim, 2008).

Tabel I. Hasil penetapan susut pengeringan paprika kuning

\begin{tabular}{ccc}
\hline Replikasi & \% Susut Pengeringan Rata-rata \pm SD (\%) \\
\hline 1 & 6,34 & $6,33 \pm 0,02$ \\
2 & 6,31 & \\
3 & 6,33 & \\
\hline
\end{tabular}

\section{Hasil ekstraksi buah paprika kuning}

Buah paprika kuning diekstraksi dengan cara maserasi menggunakan pelarut metanol, yang sifatnya semi polar. Penggunaan pelarut tersebut dimaksudkan supaya semua senyawa yang terkandung dalam paprika kuning dapat tersari secara sempurna, baik yang bersifat polar maupun non polar (Warsi and Guntarti, 2016). Hasil ekstraksi buah paprika kuning segar, dari $200 \mathrm{~g}$ simplisia basah diperoleh bobot ekstrak sebanyak 16,41 g. Rendemen yang diperoleh ialah 8,21\%.

\section{Hasil analisis kandungan $\beta$-karoten dalam ekstrak paprika kuning}

Hasil analisis kandungan $\beta$-karoten pada ekstrak buah paprika kuning dilakukan secara kualitatif menggunakan kromatografi lapis tipis (KLT), sebagai pembanding digunakan $\beta$-karoten. Hasil analisis ini menunjukkan bahwa $\mathrm{Rf}$ sampel ada yang sama dengan $\beta$-karoten (Tabel II dan Gambar 2). Berdasarkan hasil tersebut dapat diketahui bahwa buah paprika kuning mengandung senyawa karotenoid, diantaranya ialah $\beta$-karoten.

Tabel II. Hasil perhitungan Rf ekstrak paprika kuning dan $\beta$-karoten

\begin{tabular}{ccc}
\hline Sampel & n-heksan:aseton (1:2) & n-heksan:aseton (3:2) \\
\hline \multirow{3}{*}{ Ekstrak } & $\mathrm{Rf}_{1}: 0,88$ & $\mathrm{Rf}_{1}: 0,55$ \\
& $\mathrm{Rf}_{2}: 0,95$ & $\mathrm{Rf}_{2}: 0,70$ \\
B-karoten & $\mathrm{Rf}: 0,95$ & $\mathrm{Rf}_{3}: 0,94$ \\
\hline
\end{tabular}



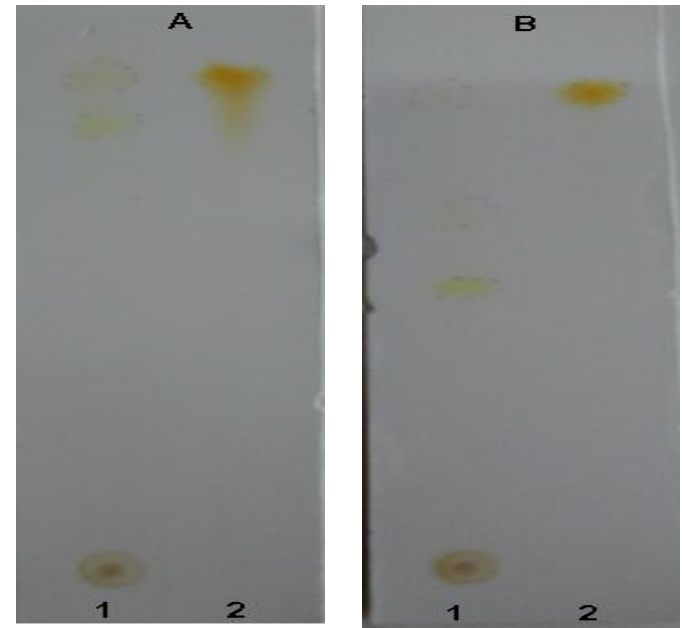

Gambar 2. Hasil analisis dengan KLT; FD silika GF 254 ; FG n-heksan-aseton 1:2 (A), 3 : 2 (B); ekstrak (1); $\beta$-karoten (2); deteksi sinar tampak

Analisis kandungan $\beta$-karoten dalam ekstrak paprika kuning juga dilakukan berdasarkan spektrumnya yang diukur dengan spektrofotometer UV-Vis, sebagaimana tersaji pada Gambar 3. Hasil pengukuran panjang gelombang serapan maksimum ekstrak paprika kuning diperoleh 475,2; 448,4; 356,0; 287,4 dan 202,2 nm. Sedangkan panjang gelombang serapan maksimum $\beta$-karoten yaitu 474,6; 450,0 dan 348,6 nm (Warsi dan Guntarti, 2013). Berdasarkan hasil pengukuran tersebut, terdapat serapan yang berasal dari ikatan rangkap terkonjugasi yang panjang (475,2 dan 448,4 nm) seperti halnya $\beta$-karoten. Selain itu, juga terdapat serapan yang berasal dari gugus keton $\alpha$, $\beta$-tidak jenuh $(356,0 \mathrm{~nm})$, gugus karbonil $(287,4 \mathrm{~nm})$ dan benzen $(202,2 \mathrm{~nm})$ (Sastrohamidjojo, 1991).

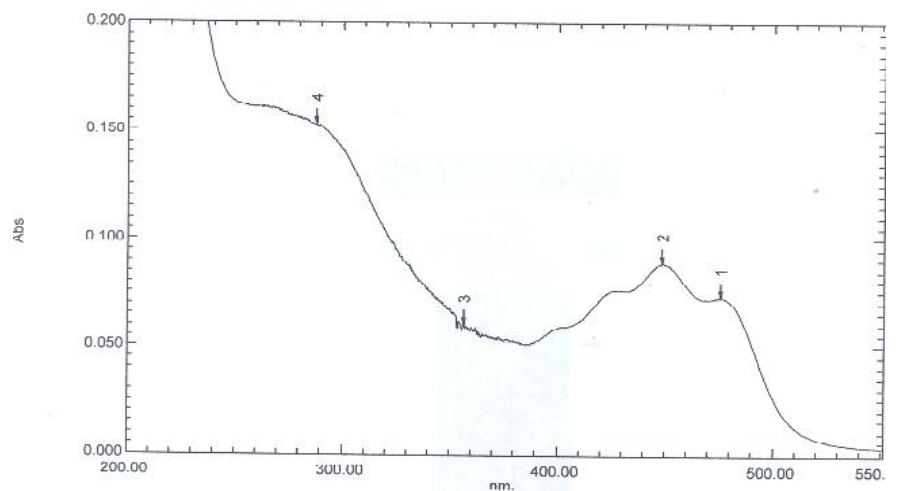

Gambar 3. Spektrum ekstrak metanol paprika kuning pada spektrofotometer UV-Vis dalam pelarut metanol

\section{Hasil analisis aktivitas antioksidan}

Aktivitas antioksidan dengan metode penangkapan radikal DPPH berdasarkan kemampuan senyawa sampel dalam mendonorkan elektronnya ke DPPH. Kemampuan tersebut dapat dilihat dari intensitas hilangnya warna ungu dari larutan DPPH. Hilangnya intensitas warna ungu DPPH dapat diukur secara kuantitatif secara spektrofotometri pada panjang gelombang 515,6 nm. Absorbansi yang terukur pada pengukuran ini ialah serapan sisa DPPH yang tidak bereaksi dengan senyawa antioksidan. Semakin besar konsentrasi sampel, dihasilkan absorbansi yang semakin kecil. Hal ini dihasilkan aktivitas \% inhibisi yang semakin besar (Gambar 4). Pada penelitian ini, untuk pembacaan sampel maupun pembanding ( $\beta$-karoten) digunakan blanko yang berisi metanol dan masing-masing seri larutan yang diukur. Hal ini karena sampel maupun pembanding merupakan larutan yang berwarna dan panjang gelombang serapan maksimalnya berdekatan dengan DPPH, sehingga dapat 
menambah absorban dari DPPH sisa yang terukur. Hasil analisis aktivitas antioksidan ekstrak paprika kuning dengan metode DPPH tersaji pada Tabel III.

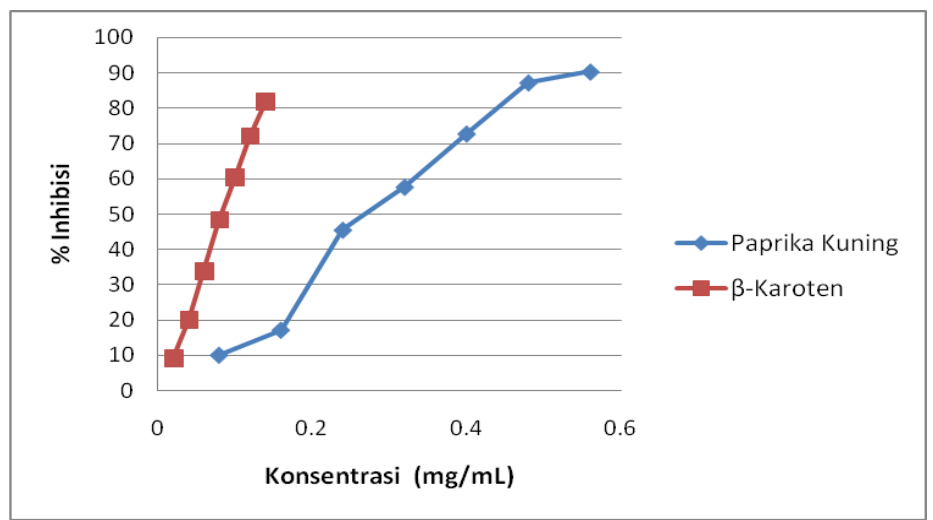

Gambar 4. Grafik rerata \% inhibisi ekstrak paprika kuning dan $\beta$-karoten

Hasil perhitungan nilai $\mathrm{IC}_{50}$ ekstrak metanol paprika kuning yang telah diperoleh dilakukan analisis secara statistik dan dibandingkan dengan $\beta$-karoten pada taraf kepercayaan $95 \%$. Hasil analisis distribusi normal dengan uji kolmogorov-Smirnov diperoleh nilai signifikansi $0,014<0,05$. Hasil tersebut menunjukkan bahwa data tidak terdistribusi normal. Hasil analisis homogenitas varian dengan uji Levene diperoleh nilai signifikansi 0,345>0,05, memperlihatkan bahwa data homogen. Data tidak terdistribusi normal, sehingga dilanjutkan dengan analisis non parametrik yaitu uji MannWhitney. Hasil analisis tersebut diperoleh nilai signifikansi $0,029<0,05$. Hal ini menunjukkan bahwa aktivitas antioksidan paprika kuning berbeda signifikan apabila dibandingkan dengan $\beta$-karoten.

Tabel III. Hasil analisis aktivitas antioksidan ekstrak paprika kuning dengan metode DPPH

\begin{tabular}{lccc}
\hline \multicolumn{1}{c}{ Sampel } & $\begin{array}{c}\text { Rerata }_{\mathbf{I C}_{50}} \pm \mathbf{S D} \\
(\mathrm{mg} / \mathrm{mL})\end{array}$ & $\mathrm{CV}(\%)$ & Hasil Analisis Statistika \\
\hline Paprika Kuning & $0,3028 \pm 0,0093$ & 3,06 & $\mathrm{p}=0,029<0,05$ \\
& & & \\
\hline -karoten & $0,0852 \pm 0,0009$ & 0,30 & \\
\hline
\end{tabular}

Berdasarkan analisis yang tertera pada Tabel III, diketahui bahwa aktivitas antioksidan buah paprika kuning kurang poten apabila dibandingkan dengan $\beta$-karoten. Namun aktivitas antioksidan paprika kuning lebih poten apabila dibandingkan dengan paprika hijau $\left(\mathrm{IC}_{50}=0,3399 \pm 0,01408\right.$ $\mathrm{mg} / \mathrm{mL}$ ) (Warsi and Guntarti, 2013) tetapi kurang poten apabila dibandingkan dengan paprika merah $(0,2992 \pm 0,00498 \mathrm{mg} / \mathrm{mL}$ ) (Warsi and Guntarti, 2016). Peneliti lain telah menguji aktivitas antioksidan ekstrak etanol paprika kuning secara in vitro dengan metode $\beta$-carotene bleaching test dihasilkan nilai $\mathrm{IC}_{50}$ sebesar $2,5 \pm 0,001 \mu \mathrm{g} / \mathrm{mL}$. Dalam penelitian tersebut vitamin $\mathrm{C}$ digunakan sebagai pembanding diperoleh nilai $\mathrm{IC}_{50}$ sebesar $1,0 \pm 0,01 \mu \mathrm{g} / \mathrm{mL}$ (Tundis et al., (2013). Nilai $\mathrm{IC}_{50}$ ekstrak etanol paprika kuning hampir sama dengan vitamin C. Berdasarkan hasil penelitian tersebut membuktikan bahwa paprika kuning juga aktif sebagai antioksidan yang diuji dengan metode lain.

Buah paprika kuning mengandung senyawa karotenoid, diantaranya adalah kapsaisin dan dihidrokapsaisin yang berperan sebagai antioksidan. Mekanisme reaksi senyawa karotenoid sebagai antioksidan diwakili oleh kapsaisin, digambarkan seperti mekanisme butil hidroksi toluen dalam menangkap radikal DPPH (Gambar 5). Kapsaisin, dalam mekanisme reaksi tersebut, mendonorkan elektron ke radikal DPPH dan terbentuk $\mathrm{DPPH}_{2}$ yang stabil. Kapsaisin setelah mendonorkan elektronnya ke radikal DPPH, berada dalam bentuk oksi radikal, kemudian mengalami delokalisasi dari elektronnya dan terbentuk struktur kuinoid dengan melepaskan satu atom $\mathrm{H}$ (Bondet et al., 1997). 
Adanya aktivitas antioksidan dari buah paprika kuning dengan mekanisme tersebut, sehingga dapat dimanfaatkan untuk mengatasi serangan radikal bebas.

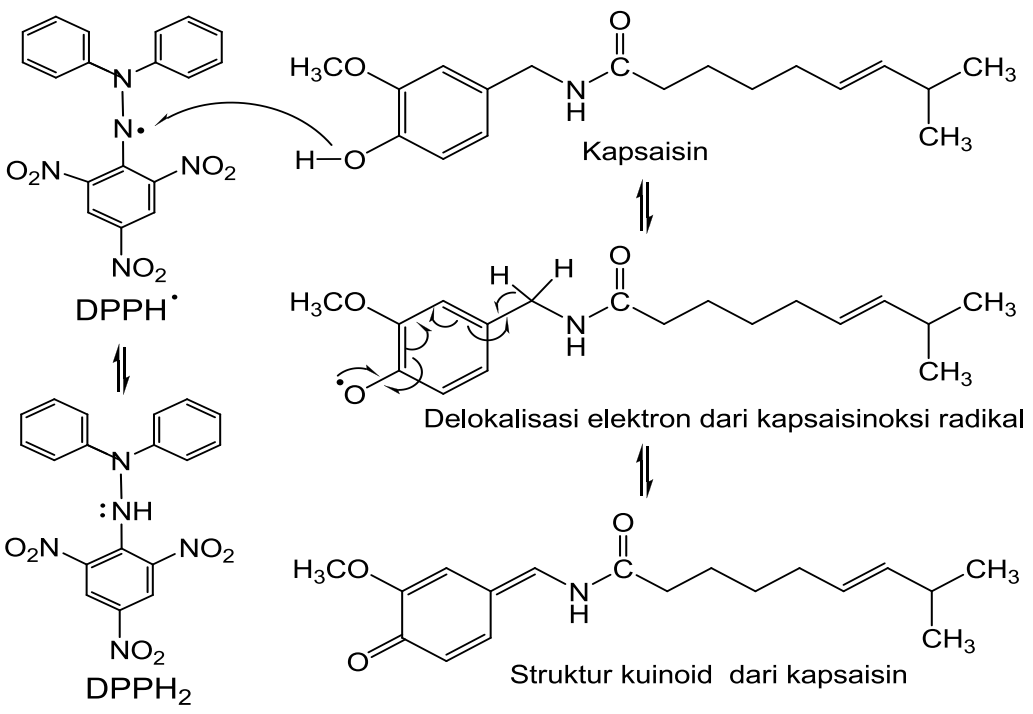

Gambar 5. Mekanisme reaksi antioksidan dari kapsaisin (Bondet et al., 1997)

\section{KESIMPULAN}

Ekstrak metanol paprika kuning mempunyai aktivitas antioksidan dengan nilai $\mathrm{IC}_{50}$ sebesar $0,3028 \pm 0,0093 \mathrm{mg} / \mathrm{mL}$. Aktivitas antioksidan ekstrak metanol paprika kuning kurang poten apabila dibandingkan dengan $\beta$-karoten $\left(\mathrm{IC}_{50}=0,0852 \pm 0,0009 \mathrm{mg} / \mathrm{mL}\right)$.

\section{DAFTAR PUSTAKA}

Anonim, 1979, Farmakope Indonesia, Edisi III, Departemen Kesehatan Republik Indonesia, Jakarta. XXXIII, 813.

Anonim, 2008, Farmakope Herbal Indonesia, Edisi I, Departemen Kesehatan Republik Indonesia, Jakarta.

Bondet, V., Brand-Williams, W., and Berset, C., 1997, Kinetics and Mecanism of Antioxidant Activity Using The DPPH· Free Radical Method, Lebens.-Wiss.u.Technol., 30: 609-615.

Cháves-Mendosa, C., Sanchez, E., Munoz-Marquez, E., Sida-Arreola, J.P., and Flores-Cordova, M.A., 2015, Bioactive Compounds and Antioxidant Activity in Different Grafted Varieties of Bell Pepper, Antioxidant, 4: 427-446.

Gülçin, I., 2007, Comparison of Iin Vitro Antioxidant and Antiradical Activities of L-Tyrosine and LDopa, Amino Acids, 32: 431-438.

Jeong, C.H., Ko, W.H., Cho, J.R., Ahn, C.G., and Shim, K.H., 2006, Chemical components of Korean paprika according to cultivars, Korean Journal Food Preservative, 13: 43-49.

Kim, J.S., Lee, W.M., Rhee, H.C. and Kim, S., 2016, Red Paprika (Capsicum annuum L.) and Its Main Carotenoids, Capsanthin and $\beta$-Carotene, Prevent Hydrogen Peroxide-induced Inhibition of Gap-junction Intercellular Communication, Chemico-Biological Interactions, 254: 146-155.

Pervical, M., 1998, Antioxidant, Clinical Nutrition Insights, NUT031 1/96 Rev. 10/98.

Purwitasari, D., 2017, Isolasi dan Aktivitas Antioksidan Isolat-2 Buah Paprika Merah (Capsicum annuиm L.) dengan Metode Penangkapan Radikal DPPH, Skripsi, Fakultas Farmasi Universitas Ahmad Dahlan, Yogyakarta. 
Reyes-Escogido, M.L., Gonzales, E.G., and Vazquez-Tzompantzi, E., 2011, Chemical and Pharmacological Aspects of Capsiacin, Review, Molecule, 16: 1253-1270.

Sastrohamidjojo, H., 1991, Spektroskopi, Edisi Kedua, Cetakan Pertama, Liberty, Yogyakarta, 28-36.

Sharma, O.P., and Bhat, T.K., 2009, DPPH Antioxidant Assay Revisited, Food Chemistry, 113: $1202-1205$.

Tundis, R., Menichini, F., Bonesi, M., Conforti, F., Statti, G., Menichini, F., and Loizzo, M. R., 2013, Antioxidant and Hypoglycaemic Activities and Their Relationship to Phytochemicals in Capsicum annuum Cultivars During Fruit Development, LWT-Food Sience and Technology, 53: 370-377.

Warsi dan Guntarti, A., 2013, Aktivitas Antioksidan Ekstrak Metanol Buah Paprika Hijau (Capsicum annuum L.), Pharmaciana, 3 (1): 9-20.

Warsi dan Guntarti, A., 2016, Aktivitas Penangkapan Radikal 2,2-Difenil-1-pikrilhidrazil (DPPH) oleh Ekstrak Metanol Paprika Merah (Capsicum annuum L.), Media Farmasi, 13 (1):23-34. 
